\title{
"The life of words" in Romanian verbal idioms with key element of Turkish origin
}

\author{
Firdes Veli Musledin* \\ Faculty of Letters, “Ovidius” University, Aleea Universității 1, 900472 Constanța, Romania
}

\section{Article info}

History:

Received January 31, 2019

Accepted February 19, 2019

Published May 7, 2019

Key words:

verbal idioms

Romanian

Turkish

loan

semantic evolution

\begin{abstract}
The present study analyzes an aspect of the formation and circulation in time and space of Romanian verbal idioms with key elements of Turkish origin. More precisely, we are thinking about the changes of meaning in Romanian as a result of the integration of the respective Turkish loans, in phrases that are old Turkish, but which mostly developed in Romanian language. The process of the linguistic contact has not always been smooth, obvious. The phrases have been subjected to eras in which meaning became opaque, then to periods in which they were revitalized, into new forms. To the difficulties created by the selection of the key terms of the old and/or regional layers of the Turkish language, we add their use in similar conditions (archaicity etc.) in Romanian, with additional connotative, metaphoric charge. The mechanisms are mostly known from historical semantics: metaphor, adaptation to the socio-cultural context etc., and the result is the permanent enrichment and modeling of the Romanian language.
\end{abstract}

\section{Semantic disambiguation}

The seniority of the key terms, on one hand and the metaphorical value they acquire in Romanian, on the other hand, make it difficult to understand the general meaning of the verbal idioms based on words of Turkish origin. The opacity manifests for the Romanian speakers nowadays, but we are convinced that many such idioms were hard to decipher in the past also, given the narrow, strictly specialized circulation of the words that generated the respective verbal constructions, as well as the connotations with which the speakers imprinted them, in a certain context, limited in space and time. That's why users who were fully aware of them, were trying, often spontaneously, to explain them somehow.

\subsection{Contextual disambiguation}

In some cases, these are relatively well-known keywords but are used in ad hoc creations, which lexicographers record, however, as if they were usual in certain epochs, because they are attested in the texts stripped off by them.

For example, starting from saftea, there are idioms well known even today: a face safteaua, with structures largely known with the meaning 'sell/buy something advantageously from the first hour of the day, from the beginning of the week', etc. and, hence, 'staring something in a good manner'. But, precisely because of the intense movement in time and space, beyond the business environment, the term favoured less ordinary verbal idioms:

a face saftea cu o oală (cu un pahar) de luni dimineață 'to break by mistake (a pot, a glass)';

a face cuiva saftea pe spinare 'to beat someone'.

*Email address: mfirdes@yahoo.com. 
In both cases, only association with certain terms included in the idiom structure helps us understand correctly its meaning: 'pot, glass', in the first example, 'back', in the second.

In their absence, the final meaning would have been difficult to understand, especially since the verbal structure is used in an ironic sense, with the negative recovery of the term, meaning the exact opposite of a term that means, in principle, 'a positive achievement,' 'a profitable business', 'good start' and 'luck'.

It is, I would say, what Coseriu (1956) called „lexical solidarities”, that is, the association in a certain context of two or more terms that together generate a meaning that did not belong to any of them, taken separately.

In the first of the two above examples, the complementary determination 'Monday morning' would no longer have been necessary, logically speaking, but its use strengthens the idea of 'bad luck', taken from popular ironic speech, for it refers to the temporal determination of saftea meaning 'good fortune in the beginning. On the other hand, the construction falls into the typology of "sayings", which refers either to the idea of 'beginning in an unlucky manner' or 'broken pots':

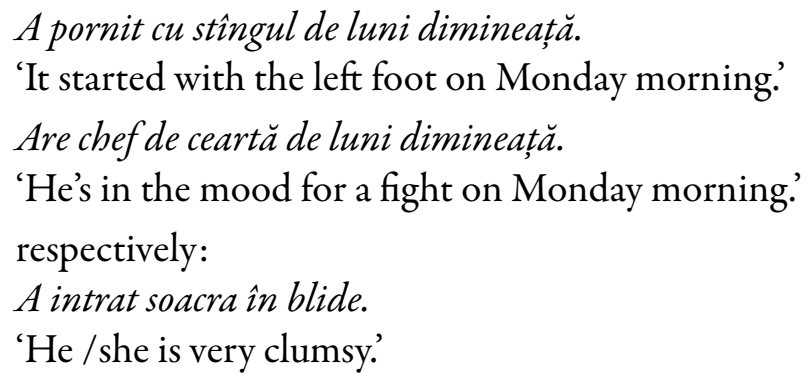

In the second example, references from DLR to several sources show that I.L. Caragiale's character uses the construction a face saftea pe spinare as an expression known in his time and in his environment, and only the extra explanations about the so called inauguration of the whip ("St. Nicholas") belong to the playwright, contributing to a disambiguation of the idiom, for the ones who do not know it maybe, and returning to circulation that saying, through a cult text, which will become classical.

\subsection{Contextualizing metaphorical habits. Abstraction and generalization of meanings}

Numerous terms from specialized semantic spheres, such as trade and finance, units of measurement, clothing, food, household items, etc., come out of the strictly professional circuit and enter the current speech by means of idiomatic structures, by proverbs and sayings.

In all these cases, the phenomenon is based on the process of abstraction of the meaning of those terms, through the mechanisms known in historical semantics: turning into metaphors (or at least the action dominated by the metaphor subcategories - synecdoche, metonymy), the change of the socio-linguistic context (enrichment of the meaning or, meaning devaluation, changing the mentality of the speakers, and changing the knowledge system and evaluation criteria). Once they entered common speech with their abstract meaning, these terms are capable of expressing value judgments by reference to the reality that the word symbolizes in the concrete aspect of the notion rendered. Obviously, the verbal idioms in question have, without exception, metaphorical meaning.

Here are some examples that can illustrate this category of idioms, whose genesis is related to the diachronic semantics, of course, but also to the social-economic history and the history of the mentalities alike:

\footnotetext{
a avea obraz de saftian

a avea urechi de saftian

a se zbîrci saftianul
} 
It is unlikely that today's speakers will understand the meaning of such verbal idioms, since the key term, saftian, cf. Tk. sabtiyan, was part of the technical language, of reduced circulation, of craftsmen and merchants in the field of leather goods and footwear, and its wider attestations in Romanian has as limits the beginning of the eighteenth century (a document from 1702, published and commented by Iorga, 1901) and the middle of the nineteenth century (a text by V. Alecsandri, from 1840, cf. DLR, s.v.).

Apart from that, the term is rarely certified by some late chroniclers, by translators of the period mentioned above, in some folklore collections (I. Golescu, S. Fl. Marian, T. Pamfile). They seem to have entered common use, only in the first half of the nineteenth century, because the dictionaries of Romanian language (CADE, Șăineanu, Cihac, Scriban) extract their illustrative texts from the writings of Gh. Asachi, N. Balcescu, N. Filimon and others, with outdated or regional forms: săftian, sabtian, seftian, pl. saftiane and saftianuri (cf. DLR, s.v.). After this period, we only see it once in C. Hogaş's writings, or later with mannerist and calophile poets, such as R. Vulpescu. The term had already been replaced by approximate synonyms, such as cordovan or marochin.

Its basic meaning of 'fine goatskin - tanned with herbs (with embossed or colored designs) or ordinary imitation of sheepskin or calfskin leather used for leather goods or fine haberdashery' (cf. DLR, s.v.), favoured, of course, capitalizing on the idea of 'finesse' in the subjective evaluations that determined the abstraction of the word and the symbolic metaphorization of the object designated by it. Hence the metaphorical idioms appeared:

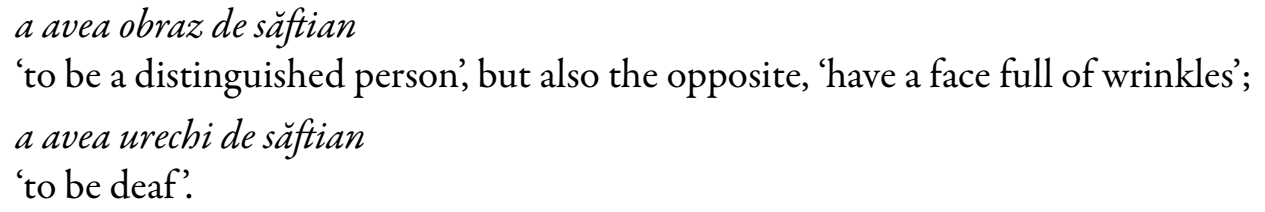

In each of these, the softness and the finesse of the leather becomes a symbol for a certain status - social or physiological, in a positive or negative sense. In the perception of the message what matters, as in the situations presented in the preceding paragraph are the additional terms, the landmark terms that help to disambiguate the constructions, respectively cheeks and ears. Both can generate by themselves metaphorical expressions for value judgments formulated in the popular register:

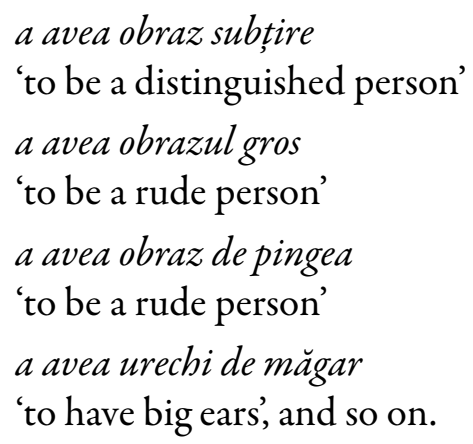

In addition, the productivity of the key word, saftian, is enhanced by the extensions of meaning to which it is subjected, according to the same mechanisms as recorded by historical semantics. When the change occurs through what we call the constraint of meaning, we remain in the denotative sphere of preserving the concrete meaning of the word. It is about using it to designate the word the top of the boot, the part that must be softer in the structure of that type of footwear, used in Muntenia and Oltenia (cf. DLR, s.v.). This is about a synecdoche, the subtype pars pro toto, totum pro part, used in such situations of semantic changes.

In other cases, the extension was made by the metaphorical association itself: saftian cheek > cheek skin $>$ cheek, face.

Lexicographies send to old texts for a phrase like this: 
a îmbătrînit rău, is-a zbîrcit saftianul...

'he grew old, his cheeks (face) wrinkled...'

In these cases, we obviously have to do with the figurative use of the term saftian.

One should also add, that the presence in these idioms of the verbs to have and to be (sometimes they are only implied) on one hand, and of the reference terms, logical and grammatical determinants for the evaluative values, meaning attributes of the support words, on the other hand, may justify the fragmentary analysis of those structures, which would point us to affirm that these words are more part of adjectival, substantive and sometimes adverbial idioms, rather than part of verbal idioms:

obraz de saftian 'wrinkles' or 'aged face', but also 'educated person', 'distinguished person'; urechi de saftian 'deafness', 'deaf person'.

Only the idiom a se zbirci saftianul is surely and exclusively verbal, because it fulfils all the conditions for the forming of the idioms we are talking about in the present study:

- it is used with a support verb from another semantic and grammatical sphere than the auxiliaries and copulatives (to have, to be, to become, etc.);

- it does not need a reference term (determined logically and grammatically);

- it has metaphoric value, the only one that justifies that combination of words.

\section{Directions of semantic evolution}

In many cases, the old Romanian term suffers a semantic „ennoblement” process or, in any case, a loss of meaningful negative meaning, in favour of the ironic, joking meaning, with a passage from concrete to abstract and from the referential denotative to connotative ambiguities. Zafiu (2017) is studying the history of the word bucluc 'trouble, misfortune', showing that its journey through the vocabulary of the Romanian language, for about two centuries of attestation, has gone from the concrete meaning of "more solid human excrement", recorded in the Glossary annex, of the 1871 Dictionary, by Laurian and Massim, the same one which certifies the idiom a minca bocluc "(not) telling lies', both meanings being "utterly" out of use, as it seems to the distinguished researcher. Three decades later, Șăineanu (1900) records the meaning 'disrespectful act', rewritten by Suciu (2010) in 'dirty deed', 'wickedness', etc. The fact that the old, but abstract meaning, has perpetuated in idioms such as a intra in bucluc 'getting into trouble', etc., is based on these peculiar connotations, also supported by the meanings in other Balkan languages. Zafiu (2017) invokes Bulg. bokluc, meaning 'garbage', which also has concrete semantism. However, today the word is used with a much attenuated meaning 'tangle', 'difficult situation', as we all understand from idioms like a da de bucluc 'to get into trouble', etc. The linguist from Bucharest considers that to the evolution of the term may have contributed the derived term buclucas, built with the diminutive suffix -aș, which has the familiar, hypocoristic connotations of 'little child', 'cute', and cites a text from I. Creangăs Memoirs in which the term is used with the usual funny, ambiguous values, "popa Buligă cel buclucaș” meaning 'Buligă the prankster priest'. However, as in the case of the word ghiudunea and other such words, the term has gone through a visible process of "ennoblement", common in historical semantics.

Talking about the strange ways of preserving some Turkish words in Romanian, Rodica Zafiu speaks in several of her condensed micro studies, published under the title "Păcatele limbii" [Sins of the Language]. As we have shown elsewhere, the Turkish word peșin 'cash' has long been replaced with various synonymous Romanian forms or forms borrowed from other languages: numerar 'cash' (used adjectivally or even as an adverbial idiom); cu banii jos; (cu) banii gheață (both idioms meaning 'cash') or the recent and quasigeneralized Anglicism bani cash 'cash money', reduced directly to cash, as it happened with peșin, a century ago. The quoted researcher reports a strange form in Romanian, included in the phrase Cît ai zice peștin (Zafiu, 2015a). It seems obvious that we are dealing with an overlapping of pește with peșin. The problem 
is that for today's speakers, none of the variants used in that phrase sounds too logical. R. Zafiu refers to the explanation of Dumistrăcel (2001), and argues that the very absurdity of the association of terms justifies their survival, which would reflect a cognitive schema of contrasts. Cît ai zice pește in the blink of an eye' has to be compared to Una zicem, alta facem 'we say something but we do something else'; Ussor de zis, greu de facut 'it is easier said than done', and so on. Without completely rejecting this explanation, R. Zafiu considers that it is more logical to consider the expressions that contain pesin 'cold cash' with the meaning evolving in the Romanian language to cash 'in advance', 'on the spot', 'immediately'. There are quotations from A. Pann, V. Alecsandri and I. Zanne, who confirm this new semantic values, acquired in Romanian language, explained as words coming from Muntenia region in A. Scriban's Dicționaru. So, it is very possible that over the old saying Cît ai zice pește 'very quickly' (coming from fishers' vocabulary, initially) overlapped Cît ai zicepeșin (which has the same meaning), with the result of creating a new word, formed through a synthesis with characteristics of popular etymology.

\section{Conclusions}

So, the Romanian verbal idioms built around a key term of Turkish origin often resume the usual Turkishlanguage patterns, but they develop lexical-semantic series of their own.

Most such lexical constructions dominate the end of the eighteenth century (only a small amount of written documents prevent us from establishing more intense circulation in an earlier period), then the $19^{\text {th }}$ century and almost the entire $20^{\text {th }}$ century, in spite of the modernization, respectively the occidentalization of the Romanian language, both literary and usual.

Of course, the use of these terms in syntagms, idioms, metaphorical structures, etc. prolonged their survival long after the very concepts they denominated (materials for craftsmen's workshops, units of measurement, coins, commercial trading formulas) came out of the use of the community of Romanian speakers.

However, the idea of 'evaluation', of an explicit and implicit measure, of challenge of the destiny, as well as the idea of 'good luck', of 'fairness', of inter-human confrontation, favoured the circulation and development of these idioms.

Especially their figurative, metaphorical use and the ironic, familiar, negative contexts stimulated their widening of use and persistence in Romanian - both in oral use and in the fictional, journalistic style, etc. All this gives plasticity, wealth and, in general, personality to the Romanian language, in its diachronicity.

\section{Bibliography}

\section{A. Sources}

Dimitrescu, Fl. (1958). Locuțiunile verbale în limba română, Editura Academiei, București.

Dumistrăcel, St. (2001). Pînă-n pînzele albe. Dicționar de expresii românești, Institutul European, Iași.

Suciu, E. (2010). Diç̧ionarul cuvintelor românești de origine turcă, Editura Academiei Române, București.

\section{B. References}

Bârlea, P. Gh. (2016). Traduceri și traducători. Pagini din istoria culturii române, Editura Universității „Alexandru Ioan Cuza”, Iaşi.

Bârlea, P.Gh. $\left(2013^{3}\right)$. Limba română contemporană. Fonetică - Ortografie - Vocabular, Editura MLR, București.

Coseriu, E. (1956). La creación metafórica en el lenguaje, Universidad de la República: Facultad de Humanidades y Ciencias, Intituto de Filogía - Departamento de Lingúistica, Montevideo.

Dumistrăcel, St. (1980). Lexic românesc. Cuvinte, expresii, metafore, Editura Științifică și Enciclopedică, București.

Gafton, Al. (2012). De la traducere la norma literară. Contribuția traducerii textului biblic la constituirea vechii norme literare, Editura Universității „Alexandru Ioan Cuza”, Iași.

Iorga, N. (1901). Studii și documente cu privire la istoria Românilor, vol. IV, Institutul de Arte Grafice și Editură Minerva, București.

Lakoff, G. \& Johnson, M. (1980). Metaphors We Live By, University of Chicago Press, Chicago.

Suciu, E. (2009). Influența turcă asupra limbii române, I. Studiu monografic, Editura Academiei Române, București. 
Suciu, E. (2011). 101 cuvinte de origine turcă, Editura Humanitas, București.

Şăineanu, L. (1885). Elemente turcești în limba română, în „Revista pentru istorie, arheologie și filologie”, Tipografia Academiei Române, București.

Șăineanu, L. (1900). Influența orientală asupra limbii și culturii române, I. Introducerea. II. Vocabularul, 1. Vorbe populare. 2. Vorbe istorice. Imprumuturi literare. Indice general, Editura Librăriei Socec, București.

Ülküsal, M. $\left(1966^{2}\right)$. Dobruca ve Türkler [Dobrogea și turcii], Türk Kültürünü Araștırma Enstitüsü, Ankara.

Wendt, H.F. (1960). Die turkischen Elemente im Rumänischen, Akademie-Verlag, Berlin.

Zafiu, R. (2001). Diversitate stilistică în româna actuală, Editura Universității din București, București.

Zafiu, R. (2015a). Cît ai zice peștin..., în „Dilema veche”, nr. 601, 19-25 august, p. 6, [online].

Zafiu, R. (2015b). Oja, între Occident și Orient, în „Dilema veche”, nr. 587, 14-20 mai, p. 6, [online].

Zafiu, R. (2017). Bucluc, în „Dilema veche”, nr. 685, 6-12 aprilie, p. 6, [online].

\section{Dictionaries}

Baubec, A. \& Baubec, G.D.-K. (2011). Dicționar turc-român, român-turc, Editura Ex-Ponto, Constanța.

CDER = Ciorănescu, Al. (2002). Dicționar etimologic al limbii române, Ediție îngrijită și traducere din limba spaniolă de Tudora

Șandru Mehedinți și Magdalena Popescu-Marin, Editura Saeculum I.O., București.

DLR = Sala, M. \& Mihăilă, Gh. (coord.) (2010). Dicționarul limbii române. Vol. I-XIX. Ediție anastatică, Editura Academiei

Române, București.

DȘL = Bidu-Vrănceanu, A. et al. (2005). Dicționar de științe ale limbii, Editura Nemira, București.

Nișanyan, S. $\left(2011^{2}\right)$. Index Anatolicus. Türkiye yereleșim birimlerievanteri, [online].

Sala, M. (2001). Enciclopedia limbii române, Editura Univers Enciclopedic, București.

Ts = Türkçe Sözlük [Dicționar al limbii turce], Türk Dil Kurumu Academia, Ankara. 